\title{
ON THE EXISTENCE AND UNIQUENESS OF SOLUTIONS FOR FRACTIONAL DIFFERENTIAL EQUATIONS WITH NONLOCAL MULTI-POINT BOUNDARY CONDITIONS
}

\author{
FAOUZI HADDOUCHI
}

\begin{abstract}
This paper presents some sufficient conditions for the existence of solutions of fractional differential equation with nonlocal multi-point boundary conditions involving Caputo fractional derivative and integral boundary conditions. Our analysis relies on the Banach contraction principle, Boyd and Wong fixed point theorem, Leray-Schauder nonlinear alternative. Finally, examples are provided to illustrate our main results.
\end{abstract}

Mathematics subject classification (2020): 34A08, 34B15.

Keywords and phrases: Riemann-Liouville fractional integral, Caputo fractional derivative, fractionalorder differential equations, existence, fixed point theorem, nonlocal multi-point boundary conditions.

\section{REFERENCES}

[1] R. P. Agarwal, B. Ahmad, D. Garout And A. Alsaedi, Existence results for coupled nonlinear fractional differential equations equipped with nonlocal coupled flux and multi-point boundary conditions, Chaos Solitons Fractals, 102, (2017), 149-161.

[2] R. P. Agarwal, A. Alsaedi, A. Alsharif And B. Ahmad, On nonlinear fractional-order boundary value problems with nonlocal multi-point conditions involving Liouville-Caputo derivatives, Differ. Equ. Appl., 9, 2 (2017), 147-160.

[3] B. AhmAD, A. Als AEDI AND A. AlshaRIF, Existence result for fractional-order differential equations with nonlocal multi-point-strip conditions involving Caputo derivative, Adv. Differ. Equ., 348, (2015), $11 \mathrm{pp}$.

[4] B. Ahmad, A. Alsaedi And D. Garout, Existence results for Liouville-Caputo type fractional differential equations with nonlocal multi-point and sub-strips boundary conditions, Comput. Math. Appl., (2016).

[5] B. Ahmad, S. K. Ntouyas, R. P. Agarwal And A. Als Aedi, Existence results for sequential fractional integro-differential equations with nonlocal multi-point and strip conditions, Bound. Value Probl., 205, (2016), 16 pp.

[6] D. Bin AND P. Huinui, Existence results for the fractional differential equations with multi-strip integral boundary conditions, J. Appl. Math. Comput., 59, 1-2 (2019), 1-19.

[7] D. W. Boyd And J. S. W. Wong, On nonlinear contractions, Proc. Amer. Math. Soc., 20, (1969), 458-464.

[8] A. Granas and J. Dugundu, Fixed Point Theory, Springer-Verlag, New York, 2003.

[9] Y. GUO, Y. JI AND X. LIU, Multiple positive solutions for some multi-point boundary value problems with p-Laplacian, J. Comput. Appl. Math., 216, 1 (2008), 144-156.

[10] F. HAdDOUCHI, Existence results for a class of Caputo type fractional differential equations with Riemann-Liouville fractional integrals and Caputo fractional derivatives in boundary conditions, arxiv.org/abs/1805.06015, 2018.

[11] J. Henderson AND R. LuCA, Systems of Riemann-Liouville fractional equations with multi-point boundary conditions, Appl. Math. Comput., 309, (2017), 303-323.

[12] M. JIA, X. ZHANG AND X, GU, Nontrivial solutions for a higher fractional differential equation with fractional multi-point boundary conditions, Bound. Value Probl., 2012, 70 (2012), 16 pp. 
[13] A. A. Kilbas, H. M. SRivastava And J. J. Trujillo, Theory and Applications of Fractional Differential Equations, North-Holland Mathematics Studies, vol. 204, Elsevier, Amsterdam, 2006.

[14] Y. LI AND A. QI, Existence of positive solutions for multi-point boundary value problems of Caputo fractional differential equation, Int. J. Dyn. Syst. Differ. Equ., 7, 2 (2017), 169-183.

[15] Y. LiU, Solvability of multi-point boundary value problems for multiple term Riemann-Liouville fractional differential equations, Comput. Math. Appl., 64, 4 (2012), 413-431.

[16] F. C. Meral, T. J. Royston And R. Magin, Fractional calculus in viscoelasticity: an experimental study, Commun. Nonlinear Sci. Numer. Simul., 15, 4 (2010), 939-945.

[17] K. S. Miller And B. Ross, An Introduction to the Fractional Calculus and Fractional Differential Equations, Wiley, New York, 1993.

[18] R. Nigmatullin, T. OMAY AND D. BALEANu, On fractional filtering versus conventional filtering in economics, Commun. Nonlinear Sci. Numer. Simul., 15, 4 (2010), 979-986.

[19] K. B. Oldham, Fractional differential equations in electrochemistry, Adv. Eng. Softw., 41, 1 (2010), 9-12.

[20] K. B. Oldham And J. Spanier, The Fractional Calculus, Academic Press, New York, 1974.

[21] E. ORSINGHER AND L. BEGHIN, Time-fractional telegraph equations and telegraph processes with brownian time, Probab. Theory. Related. Fields., 128, 1 (2004), 141-160.

[22] I. Podlubny, Fractional Differential Equations, Academic Press, Inc., San Diego, 1999.

[23] Y. P. Sun AND M. ZhaO, Positive solutions for a class of fractional differential equations with integral boundary conditions, Appl. Math. Lett., 34, (2014), 17-21.

[24] Y. WANG, S. LIANG AND Q. WANG, Existence results for fractional differential equations with integral and multi-point boundary conditions, Bound. Value Probl., 4, (2018), 11 pp.

[25] Y. Y. YANG AND Q. R. WANG, Positive solutions of multi-point boundary value problems, Electron. J. Differ. Equ., 231, (2016), 9 pp.

[26] Y. ZHANG AND Y. GU, Eigenvalue intervals for nonlocal fractional order differential equations involving derivatives, J. Appl. Math. Comput., 55, 1-2 (2017), 119-134.

[27] X. Zhang, L. LiU, B. Wiwatanapataphee And Y. WU, Solutions of eigenvalue problems for a class of fractional differential equations with derivatives, Abstr. Appl. Anal., 2012, Article ID 512127 (2012), 16 pp.

[28] X. Zhang, L. LiU AND Y. WU, The eigenvalue problem for a singular higher order fractional differential equation involving fractional derivatives, Appl. Math. Comput., 218, 17 (2012), 85268536.

[29] X. ZHANG, L. LIU AND Y. WU, The uniqueness of positive solution for a singular fractional differential system involving derivatives, Commun. Nonlinear Sci, Numer. Simul., 18, 6 (2013), 1400-1409.

[30] K. ZHAO, Triple positive solutions for two classes of delayed nonlinear fractional FDEs with nonlinear integral boundary value conditions, Bound. Value Probl., 181, (2015), 20 pp.

[31] K. ZHAO AND P. GONG, Positive solutions of m-point multi-term fractional integral BVP involving time-delay for fractional differential equations, Bound. Value Probl., 19, (2015), 19 pp.

[32] K. ZHAO AND J. LIANG, Solvability of triple-point integral boundary value problems for a class of impulsive fractional differential equations, Adv. Differ. Equ., 50, (2017), 19 pp.

[33] K. ZHAO AND K. WANG, Existence of solutions for the delayed nonlinear fractional functional differential equations with three-point integral boundary value conditions, Adv. Differ. Equ., 284, (2016), $18 \mathrm{pp}$. 